\title{
Estimation of diversity and combining abilities in Helianthus annuus L. under water stress and normal conditions
}

\author{
M. Saba ${ }^{1}$, F.A. Khan ${ }^{1}$, H.A. Sadaqat ${ }^{1}$ and I.A. Rana $^{2}$ \\ ${ }^{1}$ Department of Plant Breeding and Genetics, University of Agriculture, \\ Faisalabad, Pakistan \\ ${ }^{2}$ Centre for Agricultural Biochemistry and Biotechnology, \\ University of Agriculture, Faisalabad, Pakistan \\ Corresponding author: M. Saba \\ E-mail: diyapbg@yahoo.com
}

Genet. Mol. Res. 15 (4): gmr15048670

Received March 29, 2016

Accepted July 14, 2016

Published October 24, 2016

DOI http://dx.doi.org/10.4238/gmr15048670

Copyright (C) 2016 The Authors. This is an open-access article distributed under the terms of the Creative Commons Attribution ShareAlike (CC BY-SA) 4.0 License.

\begin{abstract}
Sunflower cannot produce high yields under waterlimiting conditions. The aim of the present study was to prevent the impediments on yield and to develop varieties with high-yield potential under water scarce conditions. For achieving this objective, it is necessary to detect parents with desirable traits that mainly depend on the action of genes controlling the trait under improvement, combining ability, and genetic makeup of the parents. Heterosis can also be used to pool the desirable genes from genetically divergent varieties and these divergent parents could be detected by molecular studies. Ten tolerant and five susceptible tester lines were selected, crossed, and tested for genetic diversity using simple sequence repeat primers. We identified two parents (A-10.8 and G-60) that showed maximum (46.7\%) genetic dissimilarity. On an average 3.1 alleles per locus were detected for
\end{abstract}


twenty pair of primers. Evaluation of mean values revealed that under stress conditions the mean performances of the genotypes were reduced for all traits under study. Parent A-10.8 was consistent as a good general combiner for achene yield per plant under both non-stress and stress conditions. Line A-10.8 in the hybrid A-10.8 x G-60 proved to be a good combiner as it showed negative specific combining ability (SCA) effects for plant height and internodal length and positive SCA effects for head weight, achene yield per plant, and membrane stability index. Valuable information on gene action, combining ability, and heterosis was generated, which could be used in further breeding programs.

Key words: Combining ability; Line $\mathrm{x}$ tester; SSR; Water stress tolerance

\section{INTRODUCTION}

In the present era of intense worldwide economic competition, only the countries with secure food production can make rapid progress. Edible oilseed crops in Pakistan can be classified as traditional (rapeseed, mustard, groundnut, sesame, cotton) and nontraditional (sunflower, soybean, and safflower). Rapeseed and mustard oils are not used as regular cooking oils because of the presence of high concentrations of erucic acid; not more than $5 \%$ of these oils are used for blending in the manufacturing of "ghee", which is clarified butter. Sunflower oil can play a significant role in bridging the gap between the production and consumption of edible oils in Pakistan (Khan et al., 2003). Seeds of sunflower contain 35-45\% oil.

Water availability is the key aspect that defines yield potential of plants. About one-fourth of world's productive regions are under drought stress (Singh, 2000). Drought stress has detrimental effects on the yield and percentage of oil in the seeds (Razi and Assad, 1998); at the flowering stage, it causes a huge decrease in yield of sunflower (Rauf, 2008). In general, physiological modifications that occur in plants in response to water stress include reduction in leaf area, closure of stomata, loss of turgor, and decrease in cell enlargement. These modifications ultimately result in a decrease in photosynthesis and respiration (Human et al., 1990), leading to an overall reduction in the production of crops. Sunflower has potential for tolerating water stress because of its well-developed root system and capacity to avoid transient wilting. To withstand water stress, tolerant genotypes with low water requirements are needed. Most of the vegetative features are influenced by environmental factors and express continuous variation besides exhibiting high degree of plasticity. Biochemical and molecular techniques have been used to inspect genetic variability, and to solve taxonomic and phylogenetic problems. The study of phylogenetic and taxonomic relationships requires a flexible and reliable marker system to detect high levels of DNA polymorphism. In the present study, simple sequence repeats (SSR), which are considered highly reliable, reproducible, and authentic DNA markers, were used to determine the diversity in sunflower (Dehmer and Friedt, 1998; Iqbal et al., 2011). The information obtained using SSR markers would be valuable for plant breeders interested in developing improved local hybrid with better achene and oil quality. To develop varieties with high-yield potential under low water conditions, it is desirable to combine the genes from genetically divergent parents. To successfully identify such parents, information about the gene action that controls the trait under improvement, combining ability, and genetic makeup of different varieties is mandatory. For generating

Genetics and Molecular Research 15 (4): gmr15048670 
hybrids, plant breeders use heterosis to find good combiners among genetically diverse inbred lines showing good performance. Evolving inbred lines having the desired general (GCA) and specific combining abilities (SCA) for important yield-related traits, and crossing these lines to obtain hybrids with high oil and yield potential as well as resistance to biotic and abiotic factors remains the main focus of sunflower hybrid breeding (Miller and Fick, 1997). It is critical to identify superior parents for hybridization by increasing the variability pool for selection of potential genotypes. In sunflower, heterosis can be manipulated extensively for obtaining better achene yield and oil content. Evaluation of GCA and SCA along with their mean values provides information about the breeding prospective of the material used in the study for transferring the desirable genes to next generations. There are several methods for assessing the genotypes for their combining abilities and genetic makeup; we used the line $\mathrm{x}$ tester method in this study to assess the combining ability. This is a reliable method for assessing the combining abilities and gene action underlying the traits under consideration.

\section{MATERIAL AND METHODS}

\section{Field layout and data collection}

The present study was performed in the research area of Department of Plant Breeding and Genetics (PBG) and the molecular studies were done in the Centre of Agricultural Biochemistry and Biotechnology (CABB), University of Agriculture, Faisalabad, during the year 2014. The seeds of fifteen parents and fifty hybrids were sown during the kharif growing season in 2014 under normal and drought conditions. Two rows of each parent and hybrid were grown; the inter-row and inter-plant spacing was kept at 60 and $30 \mathrm{~cm}$, respectively. Length of each line was kept at $2 \mathrm{~m}$. A randomized complete block design with three replications was followed. Three seeds per hole were sown by hand at a depth of 3 inches. All recommended agronomic and plant protection practices for normal crop cultivation were adopted uniformly for all the parents and hybrids throughout the growing season. For stress plot (rainout shelter), irrigation was stopped after the flowering stage. Thinning was performed and one healthy plant per hole was maintained. Proper care was taken to avoid bird attack. Ten plants from each replication were tagged and guarded in both normal and drought conditions. Upon maturity, plant height $(\mathrm{cm})$, head diameter $(\mathrm{cm})$, achene yield/plant $(\mathrm{g})$, relative water content (RWC) (Malik, 1995), excised leaf water loss (ELWL; Dhanda and Sethi, 1998), and membrane stability index (MSI; Premchandra et al., 1990) were measured for 10 guarded plants at flowering stage.

\section{Assessment of genetic diversity using SSR markers}

This experiment was conducted at CABB, University of Agriculture, Faisalabad. The DNA of parents was extracted and the SSRs were amplified using polymerase chain reaction (PCR) in a thermal cycler (Eppendorf AG22331, Hamburg) to estimate the genetic diversity present in the material. DNA of fifteen parents was extracted using the procedures stated by Doyle and Doyle (1990), with some amendments (Iqbal et al., 2011). Extracted DNA was quantitated using a spectrophotometer (Thermo Scientific Nanodrop 2000, USA). Working solution for each parental sample comprised $50 \mathrm{ng}$ DNA in $1 \mu \mathrm{L}$ double-distilled deionized water $\left(\mathrm{d}_{3} \mathrm{H}_{2} \mathrm{O}\right)$. The concentration of genomic DNA and reaction mixture were optimized for

Genetics and Molecular Research 15 (4): gmr15048670 
SSR analysis (Mba et al., 2001). List of primers used is presented in Table 1. Working solution of each of parental and hybrid samples containing $50 \mathrm{ng}$ DNA in $1 \mu \mathrm{L} \mathrm{d}_{3} \mathrm{H}_{2} \mathrm{O}$ was prepared. The concentration of genomic DNA, 10X PCR buffer with $\left(\mathrm{NH}_{4}\right)_{2} \mathrm{SO}_{4}, \mathrm{MgCl}_{2}$, dNTPs (dATP, dCTP, dGTP, dTTP), forward and reverse SSR primers, and Taq DNA polymerase were optimized for SSR analysis (Mba et al., 2001) Twenty pairs of forward and reverse SSR primers were obtained from Gene Link (USA) (details of primers are given in Table 1). Taq polymerase together with buffer, $\mathrm{MgCl}_{2}$, dNTPs and gelatin were purchased from Fermentas (Germany). The master mixture for fifteen parental sample reactions against one primer was prepared through mixing of $4.3 \mu \mathrm{L} \mathrm{d}_{3} \mathrm{H}_{2} \mathrm{O}, 2.0 \mu \mathrm{L} 10 \mathrm{X}$ PCR buffer, $3.0 \mu \mathrm{L}$ dNTPs, $2.5 \mu \mathrm{L}$ $\mathrm{MgCl}_{2}, 1.5 \mu \mathrm{L}$ forward primer, $1.5 \mu \mathrm{L}$ reverse primer and $0.2 \mu \mathrm{L}$ Taq polymerase. For one sample reaction, $3 \mu \mathrm{L}$ diluted DNA of each parent was mixed with $15 \mu \mathrm{L}$ master mixture in one PCR tube. DNA amplification reactions were performed on a thermal cycler (Eppendorf AG No. 533300839 ). In the thermal cycler, at $94^{\circ} \mathrm{C}$, the DNA was denatured, i.e., the two strands became separated. At $55^{\circ} \mathrm{C}$, the SSR primers (forward and reverse) anneal their respective complementary sequences on the DNA strands. At $72^{\circ} \mathrm{C}$, DNA polymerase extends the DNA chain by adding nucleotides to the ends of the primers. The PCR profile was as followed: the denaturation temperature of $94^{\circ} \mathrm{C}$ was kept for 5 min during initial cycle while it was kept for $45 \mathrm{~s}$ during the remaining 35 cycles. Annealing and extension temperatures were kept at $55^{\circ}$ $60^{\circ} \mathrm{C}$ for $45 \mathrm{~s}$ and $72^{\circ} \mathrm{C}$ for $1 \mathrm{~min}$, respectively, during 35 cycles. After completion of $35 \mathrm{PCR}$ cycles, extension temperature of $72^{\circ} \mathrm{C}$ was provided for $7 \mathrm{~min}$ for a final extension.

Table 1. Details of SSR primers used in the molecular studies.

\begin{tabular}{l|c|c|l|l}
\hline & $\begin{array}{c}\text { Marker } \\
\text { name }\end{array}$ & $\begin{array}{c}\text { Annealing } \\
\text { temperature }\end{array}$ & Forward primer (5'-3') & Reverse primer (5'-3') \\
\hline 1 & ORS-31 & $50^{\circ} \mathrm{C}$ & AAT TCA TGC CCC AAG AGA TG & CAC AAT TCA TGC ATT TCT CTG G \\
\hline 2 & ORS-149 & $50^{\circ} \mathrm{C}$ & GCTCTCTATCTCCCTTGACTCG & TGCTCTAAGATCTCAGGCGTGC \\
\hline 3 & ORS-203 & $48^{\circ} \mathrm{C}$ & GCCCAAGATGTG AAGCGAATG & GTCAGAACAGGA CCGAACCACT \\
\hline 4 & ORS-204 & $50^{\circ} \mathrm{C}$ & CGTCTGGCA TT A T GAAATCGTC & CCGCATAACAGC AATGGTCAAC \\
\hline 5 & ORS-237 & $53^{\circ} \mathrm{C}$ & CAAGGTCTGTCTACATCCCACC & GCTGTAAAGCCTGCATATCCTC \\
\hline 6 & ORS- 254 & $52^{\circ} \mathrm{C}$ & AAATCCCACTTCA TACAAACGT & CCTTCAGTGCTCA TGCAGTG \\
\hline 7 & ORS-301 & $57^{\circ} \mathrm{C}$ & CGTGACCTGTGAAACACCAA & CGATAACCGTGTGAATCGTG \\
\hline 8 & ORS-324 & $55^{\circ} \mathrm{C}$ & CACTTCTACTCCATCTTCTTCATCAA & ATGATGCTCCGCAACAGTTT \\
\hline 9 & ORS-328 & $56^{\circ} \mathrm{C}$ & GACCTGT AGGCC AATATGAGACTT & TT A T ACCGGTGTT GTATCGTATCC \\
\hline 10 & ORS-349 & $58^{\circ} \mathrm{C}$ & CCCTAACCAATATGCTCCCATT & TGGATAAACGAGTGAATGGTGT \\
\hline 11 & ORS-366 & $55^{\circ} \mathrm{C}$ & AACCAACTGAGCATTCTTGTGA & GCGCTAGGTTAAAGAGGACAA \\
\hline 12 & ORS-509 & $58^{\circ} \mathrm{C}$ & CAACGAAAAGACAGAATCGAAA & CCGGGAATTTTACAAGGTGA \\
\hline 13 & ORS-653 & $57^{\circ} \mathrm{C}$ & CACCCACCAAGA ACCCTAGA & CCGATACATACCA TAGCCGATT \\
\hline 14 & ORS- 1209 & $57^{\circ} \mathrm{C}$ & AACAAGCAAGCAAATCAACCATA & AGAATTAAACCCAACCCGGAAC \\
\hline 15 & ORS-309 & $55^{\circ} \mathrm{C}$ & CATTTGGATGGAGCCACTTT & GATGAAGATGGGGAATTTGTG \\
\hline 16 & ORS-822 & $58^{\circ} \mathrm{C}$ & CAATGCCATCTGTCATCAGCTAC & AAACAAACCTTTGGACGAAACTC \\
\hline 17 & ORS-1068 & $57^{\circ} \mathrm{C}$ & AATTTGTCGACGGTGACGATAG & TTTTGTCATTTCATTACCCAAGG \\
\hline 18 & ORS-552 & $55^{\circ} \mathrm{C}$ & CCATCCCTTCCCTCTCTTTC & GTGGCTGGAATCTCATCACC \\
\hline 19 & ORS -502 & $52^{\circ} \mathrm{C}$ & ATCCCAACAGACGCCATTAT & AGGATTGGAGGGAGCCAATA \\
\hline 20 & ORS-811 & $55^{\circ} \mathrm{C}$ & CCTTCTCCTCAATCTTTGGCTA & \\
\hline & & & &
\end{tabular}

After completion of PCR, 3.0 $\mu \mathrm{L}$ bromophenol blue was added (Mullis et al., 1994). Because of the large pore size of agarose gel, SSR fragments with minute size differences could not be separated. Therefore, to isolate such fragments and obtain distinct bands, polyacrylamide gel electrophoresis (PAGE) was performed. The amplicons generated with different SSR primers were scored as 1 or 0 for presence or absence, respectively, for all the genotypes under study. Similarity coefficient matrix among all the genotypes was computed

Genetics and Molecular Research 15 (4): gmr15048670 
according to Nei and Li (1979). A dendrogram based on these similarity coefficients was constructed with un-weighted pair group method of arithmetic means algorithm (Sneath and Sokal, 1973) using the NTSYSpc software package.

\section{Statistical and biometrical analysis}

All the studied traits were subjected to analysis of variance according to Steel et al. (1997). Data were further analyzed for GCA and SCA using line $\mathrm{x}$ tester method (Kempthorne, 1957). GCA and SCA effects were estimated.

\section{RESULTS AND DISCUSSION}

\section{Assessment of genetic diversity among parental material using SSRs}

The electrophoretic profiles of bands amplified in parents, as assessed by SDS-PAGE, were used to construct a dendrogram. Forty-three clear bands were observed on the gel. In all the plants, on an average 3.1 alleles per locus were observed with twenty SSR primer pairs. Many other bands of low molecular weight were also observed, but owing to discrepancy in reproducibility these were not included in the results. Gel picture for primer ORS-237 amplifying SSRs from fifteen parental sunflower genotypes is given in Figure 1. A Euclidean similarity coefficient matrix was calculated for parents and a dendrogram was constructed (Figure 2). Using Ward's method, three major lineage groups were revealed at a linkage distance of 10. Cluster 1 (linkage distance 4) further divided germplasm into two sub-clusters (1a and 1b). Sub-cluster 1a consisted of three genotypes namely A-11, A-10.8, and A-9 and sub-cluster $1 \mathrm{~b}$ consisted of three genotypes named A-6, RL-51, and RL-52. Cluster 2 consisted of three genotypes named C-11, B-1.10, and C-3, whereas Cluster 3 consisted of two sub-clusters, 3a and $3 \mathrm{~b}$. Sub-cluster $3 \mathrm{a}$ comprised two genotypes, B-2.8 and A-35. Sub-cluster $3 \mathrm{~b}$ comprised four genotypes, C-10, B-4, B-3, and G-60. The maximum distance was observed between A-10.8 and G-60. Darvishzadeh et al. (2010) observed 2.32 alleles per locus, and 3.5 alleles per locus were witnessed by Zhang et al. (2005) and Sujatha et al. (2008), whereas Duca et al. (2013) detected a total of 34 alleles with an average number of 3.4 alleles per locus. The contradictory results might be due to difference in the experimental conditions as well as lack of precision with ordinary gels. On the other hand, low genetic distances were observed, which indicated that the breeding material had narrow genetic base and might belong to the same geographical area. In the present study, genotypes that were susceptible to drought (used as tester) shared the same cluster whereas genotypes that were tolerant to drought (used as inbred lines) tended to cluster together. These findings were in accordance with those of Zia et al. (2014).

\section{Combining ability analysis}

\section{$G C A$}

GCA of lines for traits under study using line and tester analysis is given in Table 2 . Maximum negative GCA effects were observed in the line A-10.8 (-7.21) for plant height, under non-stress regime, whereas under stress regime, maximum negative GCA effects were observed for line A-6 (-7.55) for plant height. Results of the present study were supported by

Genetics and Molecular Research 15 (4): gmr15048670 
those of Kumar et al. (1998) and Khan et al. (2008). The difference in the findings might be due to the divergence in breeding material or it could be the effect of environment. For head diameter, line C-3 performed well. Hladni et al. (2014) and Mohyaji et al. (2014) observed highly positive GCA effects for head diameter. Line A-10.8 was consistent for GCA and SCA for achene yield per plant under both the normal and stress regimes. The results of the present study were in accordance with those of Ahmad et al. (2012), who reported significant positive GCA effects for achene yield/plant. No consistent line was found for GCA effects for physiological traits under both the regimes. Similar kind of results for ELWL and MSI were presented by Dhanda and Sethi (1998).

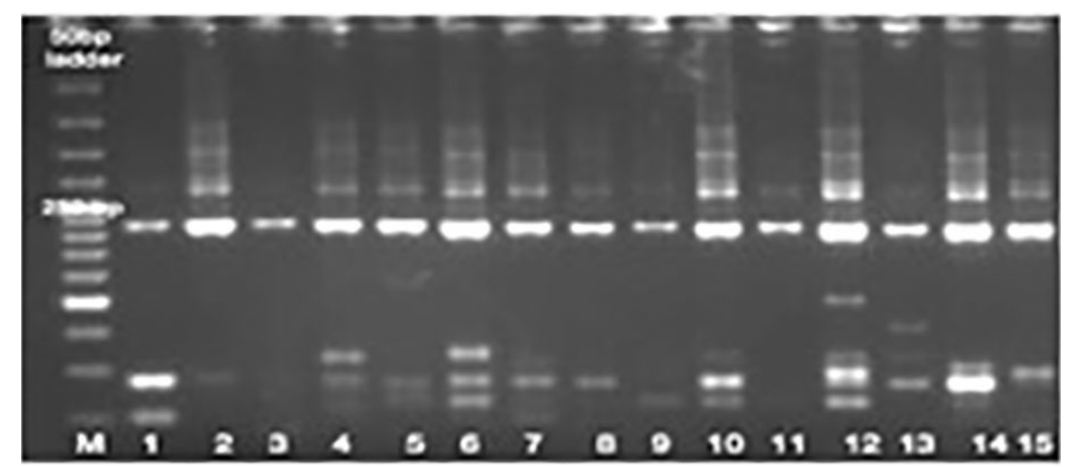

Figure 1. Gel picture for primers ORS-237 amplifying SSRs from 15 parental sunflower genotypes. Lane $M=$ DNA ladder showing different sizes for amplified fragments; lanes 1 to $15=\mathrm{SSRs}$ amplified from different parental lines (lanes 1-10 are female parents; lanes 11-15 are male parents).

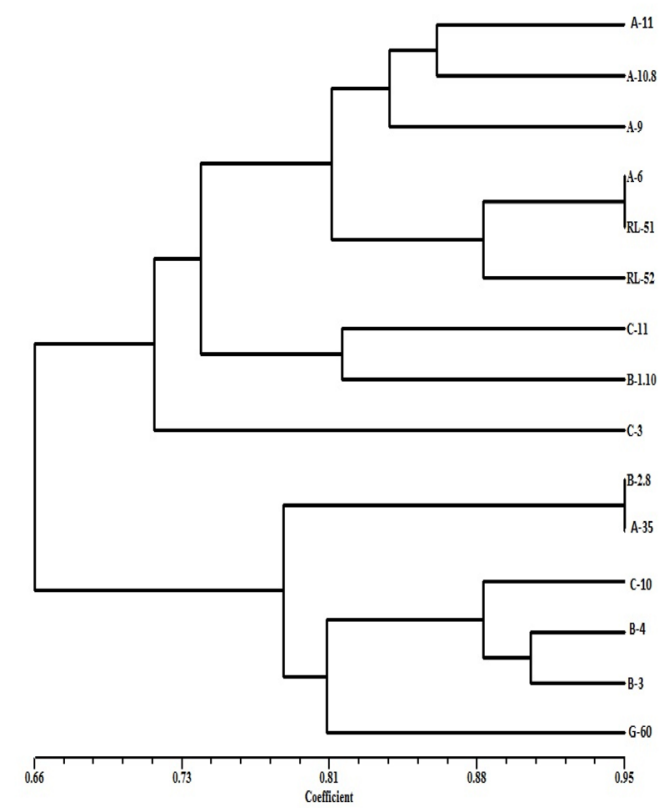

Figure 2. Dendrogram of 15 genotypes of sunflower based on SSRs amplified using 20 primer pairs.

Genetics and Molecular Research 15 (4): gmr15048670 
In short, inbred Line A-10.8 indicated highest GCA for achene yield per plant in both regimes and minimum plant height under no stress. Hence, it was proved to be a good general combiner for these traits.

Table 2. General combining ability (GCA) estimates of lines and testers for various traits under non-stressed $\left(\mathrm{W}_{1}\right)$ and stressed $\left(\mathrm{W}_{2}\right)$ conditions.

\begin{tabular}{|c|c|c|c|c|c|c|c|c|c|c|c|c|}
\hline \multirow[t]{2}{*}{ Lines } & \multicolumn{2}{|c|}{$\mathrm{PH}$} & \multicolumn{2}{|c|}{ HD } & \multicolumn{2}{|c|}{ AYP } & \multicolumn{2}{|c|}{ RWC } & \multicolumn{2}{|c|}{ ELWL } & \multicolumn{2}{|c|}{ MSI } \\
\hline & $\mathrm{W}_{1}$ & $\mathrm{~W}_{2}$ & $\mathrm{~W}_{1}$ & $\mathrm{~W}_{2}$ & $\mathrm{~W}_{1}$ & $\mathrm{~W}_{2}$ & $\mathrm{~W}_{1}$ & $\mathrm{~W}_{2}$ & $\mathrm{~W}_{1}$ & $\mathrm{~W}_{2}$ & $\mathrm{~W}_{1}$ & $\mathrm{~W}_{2}$ \\
\hline A-11 & 5.40 & 1.52 & 1.60 & -2.44 & 0.55 & -0.48 & -0.15 & -0.10 & 2.64 & 0.51 & -5.15 & -3.35 \\
\hline A-6 & 4.74 & -3.48 & -0.19 & -2.60 & -2.58 & 0.49 & 0.11 & 0.02 & 0.64 & 1.24 & -4.59 & -7.55 \\
\hline A-9 & 2.06 & 1.78 & -0.79 & -1.54 & -0.56 & $\begin{array}{l}-0.82 \\
\end{array}$ & 0.15 & 0.06 & 0.10 & 0.84 & -0.62 & -4.62 \\
\hline $\begin{array}{l}\mathrm{A} 10.8 \\
\end{array}$ & 5.77 & 0.42 & 0.92 & -1.86 & 2.69 & 1.01 & 0.07 & 0.07 & -0.49 & -0.82 & -7.21 & -4.88 \\
\hline RL-51 & 2.26 & -0.58 & 1.34 & 1.21 & 0.51 & 0.83 & 0.05 & 0.06 & -0.47 & -0.35 & 1.83 & -1.35 \\
\hline RL-52 & 0.20 & 0.52 & -3.27 & 3.09 & -2.18 & 0.54 & 0.006 & 0.05 & -1.09 & -0.48 & 8.04 & -2.02 \\
\hline $\mathrm{C}-3$ & -1.86 & -0.34 & 2.14 & 3.66 & 2.11 & -0.84 & -0.06 & 0.16 & 0.04 & 1.04 & 2.21 & -6.84 \\
\hline $\mathrm{C}-11$ & -2.26 & -4.74 & -3.32 & 1.46 & 2.40 & 0.11 & -0.05 & 0.08 & 0.44 & -0.88 & 4.79 & 2.58 \\
\hline B-1.10 & -2.32 & -1.28 & -0.86 & 0.62 & -0.80 & -0.26 & -0.02 & 0.02 & -0.22 & -0.48 & -1.83 & -3.11 \\
\hline B-2.8 & -0.86 & 4.65 & 0.74 & -2.01 & -2.13 & $\begin{array}{l}-0.60 \\
\end{array}$ & -0.12 & 0.009 & -1.56 & $\begin{array}{l}-0.62 \\
\end{array}$ & 1.98 & 1.24 \\
\hline S.E. & 0.75 & 0.84 & 1.04 & 0.86 & 0.84 & 0.88 & 0.01 & 0.01 & 0.57 & 0.83 & 3.17 & 4.4 \\
\hline \multicolumn{13}{|l|}{ Testers } \\
\hline A-35 & 0.90 & 0.38 & -0.02 & -0.37 & -0.29 & 1.08 & -0.01 & 0.014 & -0.89 & 0.21 & -0.99 & 0.54 \\
\hline $\begin{array}{l}\text { G-60 } \\
\end{array}$ & 0.34 & 0.22 & -0.69 & 0.50 & 0.57 & -0.17 & 0.02 & -0.01 & 0.26 & 0.01 & 2.60 & 2.81 \\
\hline C-10 & -0.94 & -2.21 & -0.32 & 0.17 & 0.28 & -0.27 & 0.01 & 0.03 & 0.94 & 0.08 & 0.10 & -3.88 \\
\hline B-4 & 2.52 & 0.08 & 1.40 & -0.06 & -0.16 & -0.37 & -0.001 & 0.021 & 0.34 & 0.01 & -2.26 & -2.52 \\
\hline B-3 & 0.54 & 1.52 & -0.36 & -0.23 & -0.39 & -0.25 & -0.02 & 0.025 & -0.12 & -0.32 & 0.53 & 3.04 \\
\hline S.E. & 0.53 & 0.59 & 0.73 & 0.60 & 0.59 & 0.62 & 0.01 & 0.02 & 0.10 & 0.59 & 2.24 & 3.12 \\
\hline
\end{tabular}

$\mathrm{PH}=$ plant height, $\mathrm{HD}=$ head diameter, $\mathrm{AYP}=$ achene yield per plant, $\mathrm{RWC}=$ relative water content, $\mathrm{ELWL}=$ excised leaf water loss, MSI $=$ membrane stability index.

\section{$S C A$}

SCA of lines for traits under study, using line $\mathrm{x}$ tester analysis are given in Table 3. Maximum negative SCA effects were observed for plant height in line A-10.8 (-14.03) in the A-10.8 x G-10 hybrid under non-stress regime, whereas maximum negative SCA effects were observed for line RL-51 (-19.24) in the RL-51 x G-60 hybrid under stress regime. Findings of the present study are in agreement with those of Hladni et al. (2014). Moreover, line A-11 in hybrid A-11 x G-60 was consistent for SCA of head diameter in both the conditions. The highest positive SCA effects for achene yield per plant were observed for line A-10.8 (4.90) in the A-10.8 x G-60 hybrid, under non-stressed regime, whereas under stress regime, highest positive SCA effects were observed for line A-10.8 (3.47) in the A-10.8 x G-60 hybrid. These results were in accordance with findings of previous study (Ahmad et al., 2012). Lines A-9 and RL-52 had highest SCA effects for RWC and ELWL; therefore, these lines could be used in drought breeding programs. Findings of this study were in accordance with those of Farshadfar et al. (2012), suggesting that the cell membrane stability (MSI) was mainly controlled by the dominant gene action. Contradictory results were reported by Mohyaji et al. (2014).

The inferences drawn from these results were that inbred line A-11 performed well for head diameter in hybrid A-11 x G-60 under non-stress and A-11 x B-3 under stress regimes, whereas inbred line A-10.8 proved to be good for achene yield per plant in hybrid A-10.8 x G-60. 
Table 3. Specific combining ability (SCA) estimates of crosses for various traits under non-stress $\left(\mathrm{W}_{1}\right)$ and stress $\left(\mathrm{W}_{2}\right)$ conditions.

\begin{tabular}{|c|c|c|c|c|c|c|c|c|c|c|c|c|}
\hline \multirow[t]{2}{*}{ Crosses } & \multicolumn{2}{|c|}{$\mathrm{PH}$} & \multicolumn{2}{|c|}{$\mathrm{HD}$} & \multicolumn{2}{|c|}{ AYP } & \multicolumn{2}{|c|}{ RWC } & \multicolumn{2}{|c|}{ ELWL } & \multicolumn{2}{|c|}{ MSI } \\
\hline & $\mathrm{W}_{1}$ & $\mathrm{~W}_{2}$ & $\mathrm{~W}_{1}$ & $\mathrm{~W}_{2}$ & $\mathrm{~W}_{1}$ & $\mathrm{~W}_{2}$ & $\mathrm{~W}_{1}$ & $\mathrm{~W}_{2}$ & $\mathrm{~W}_{1}$ & $\mathrm{~W}_{2}$ & $\mathrm{~W}_{1}$ & $\mathrm{~W}_{2}$ \\
\hline A-11 $\times$ A-35 & 3.26 & -11.01 & 3.82 & 0.22 & -1.58 & -4.32 & 2.24 & 1.74 & 0.03 & -0.13 & 3.44 & 1.92 \\
\hline A-11 x C-10 & -1.37 & -1.94 & 0.16 & -1.85 & 0.23 & -1.10 & 1.14 & 0.58 & -0.003 & -0.12 & 1.74 & 0.12 \\
\hline A-11 x G-60 & 1.21 & 4.42 & 5.54 & 0.13 & -0.50 & -2.96 & -0.27 & -4.98 & -0.02 & -0.03 & 1.06 & -0.94 \\
\hline A-11 x B-4 & 0.93 & 4.72 & 0.94 & -0.28 & 1.50 & -0.86 & 0.79 & -3.71 & -0.01 & 0.11 & 3.66 & -1.54 \\
\hline A-11 $\times$ B-3 & -4.03 & 3.82 & 2.49 & 1.78 & 0.34 & 0.11 & 1.90 & -1.05 & 0.37 & 0.18 & 0.46 & 0.45 \\
\hline A- $6 \times$ A-35 & 5.21 & -4.48 & -2.70 & -3.15 & 0.21 & -1.59 & 1.80 & -1.58 & 0.27 & -0.02 & 1.56 & -2.14 \\
\hline A-6 x C-10 & -10.86 & -7.41 & 1.37 & 0.44 & -1.09 & -1.40 & 2.06 & -1.75 & 0.12 & 0.04 & 0.26 & -3.61 \\
\hline A-6 x G-60 & 5.76 & 5.62 & 2.26 & -0.49 & 0.40 & -1.94 & 3.19 & 1.01 & 0.10 & 0.06 & 1.72 & -4.65 \\
\hline A-6 x B-4 & -8.59 & 0.58 & 4.86 & 0.18 & 2.38 & -3.21 & 1.46 & 1.38 & 0.01 & -0.02 & -1.34 & -1.94 \\
\hline A-6 $\times$ B-3 & 8.48 & 5.68 & 3.04 & -0.28 & 2.85 & -1.46 & 3.54 & 0.94 & 0.03 & -0.05 & -2.20 & -3.05 \\
\hline A-9 $x$ A-35 & 8.17 & 5.92 & 2.56 & -0.68 & -0.03 & -1.17 & -0.007 & -7.85 & 0.02 & -0.04 & 2.90 & -1.74 \\
\hline A-9 $\times$ C -10 & 2.24 & 8.32 & 1.89 & 0.68 & 0.42 & 0.25 & 7.86 & 4.64 & 0.04 & -0.02 & 1.46 & -1.54 \\
\hline A-9 x G-60 & -7.60 & 5.02 & 1.14 & -0.33 & -0.45 & -0.85 & 6.67 & 3.08 & 0.006 & -0.03 & 2.92 & -0.94 \\
\hline A-9 x B-4 & 0.32 & -6.01 & 2.54 & -0.42 & -0.60 & -1.75 & 1.26 & 0.44 & 0.007 & -0.006 & -3.14 & -3.78 \\
\hline A-9 $\times$ B-3 & -3.13 & -13.24 & 0.77 & -0.75 & 2.66 & 2.16 & 0.56 & -0.32 & 0.04 & 0.03 & 1.66 & 0.45 \\
\hline A-10.8 $\times$ A-35 & -5.12 & 6.52 & -0.97 & -1.98 & 3.63 & -1.33 & -0.34 & -2.54 & 0.43 & 0.20 & 2.30 & 1.58 \\
\hline A-10.8 $\times$ C-10 & $-5.35-$ & 3.58 & 2.36 & 0.04 & -0.54 & -0.56 & -5.14 & -5.38 & 0.08 & 0.05 & 1.99 & 1.78 \\
\hline A-10.8 x G-60 & -14.03 & 7.28 & -2.67 & -2.90 & 4.90 & 3.47 & 4.99 & 1.81 & -0.05 & -0.08 & 4.40 & 1.05 \\
\hline A- $-10.8 \times$ B-4 & 15.12 & -6.74 & -1.40 & -2.09 & 0.16 & -0.53 & -0.07 & -4.82 & 0.04 & -0.12 & 2.12 & -1.21 \\
\hline A-10.8 $\times$ B-3 & 9.39 & -10.64 & 2.69 & 0.97 & 2.96 & -1.71 & -0.57 & -4.92 & 0.02 & -0.05 & 2.80 & -3.21 \\
\hline RL-51 $\times$ A-35 & 6.67 & 12.98 & 3.90 & -3.60 & 0.71 & -2.63 & -0.14 & -0.68 & -0.07 & -0.14 & 2.36 & -1.21 \\
\hline RL-51 x C-10 & 6.19 & 5.38 & 1.57 & 1.19 & 2.50 & -2.62 & 1.06 & -1.48 & 0.02 & -0.17 & 2.39 & 1.32 \\
\hline RL-51 x G-60 & 7.46 & -19.24 & 2.72 & -1.05 & 0.03 & -1.74 & 1.86 & -3.38 & 0.67 & 0.22 & 1.19 & 0.25 \\
\hline RL-51 x B-4 & -12.34 & -2.94 & 1.32 & -3.52 & $\begin{array}{l}-0.22 \\
\end{array}$ & -0.88 & 2.20 & $\begin{array}{l}-0.02 \\
\end{array}$ & 0.01 & 0.08 & 3.20 & 0.65 \\
\hline RL-51 x B-3 & -7.99 & 3.82 & 1.42 & -0.07 & 2.95 & 2.63 & 0.70 & 0.21 & 0.01 & 0.01 & 1.74 & -1.01 \\
\hline RL-52 $\times$ A-35 & -0.74 & -6.68 & 0.16 & -1.94 & 0.44 & -1.48 & 0.72 & -4.34 & 0.007 & -0.03 & 1.62 & 0.92 \\
\hline RL-52 x C-10 & 4.79 & -2.94 & 1.50 & 0.18 & -1.06 & -1.44 & -1.07 & -5.15 & 0.09 & -0.06 & 1.67 & -1.54 \\
\hline RL-52 x G-60 & 4.89 & 1.42 & 2.46 & 0.37 & -0.43 & -1.95 & 0.72 & -2.38 & -0.19 & -0.27 & -0.87 & -1.05 \\
\hline RL-52 x B-4 & 4.73 & 3.38 & 0.60 & 0.41 & 3.20 & 2.47 & 0.32 & 0.28 & 0.61 & -0.01 & 0.39 & -0.54 \\
\hline RL-52 x B-3 & -13.67 & 4.82 & -0.50 & -0.98 & 0.84 & -0.50 & 2.22 & 2.01 & 0.05 & 0.06 & 1.52 & -0.88 \\
\hline C-3 $\times$ A-35 & -6.01 & -10.54 & -0.37 & -1.58 & 1.34 & -1.62 & 1.72 & 1.61 & 0.76 & 0.11 & 1.49 & 0.38 \\
\hline $\mathrm{C}-3 \times \mathrm{C}-10$ & 10.00 & -10.14 & 1.96 & 0.04 & 1.19 & -0.66 & 3.34 & 2.44 & -0.02 & -0.02 & 0.19 & -2.25 \\
\hline $\mathrm{C}-3 \times \mathrm{G}-60$ & -4.39 & 0.22 & -0.40 & -1.53 & 0.49 & -0.99 & 3.20 & 1.21 & 0.01 & -0.15 & -2.00 & -2.81 \\
\hline C-3 $\times$ B-4 & -3.10 & 11.18 & 1.47 & -0.49 & 0.44 & 0.32 & 0.39 & -4.75 & 0.10 & -0.01 & 0.59 & 0.25 \\
\hline C-3 $\times$ B-3 & 3.51 & 9.28 & 0.29 & -0.41 & 0.68 & -0.97 & 0.42 & -5.52 & 0.04 & -0.07 & 0.27 & -0.08 \\
\hline C-11 x A-35 & -7.53 & 4.38 & 0.90 & -0.45 & 1.14 & 0.81 & 0.52 & -1.98 & 0.07 & 0.04 & 0.76 & -0.01 \\
\hline C-11 x C-10 & 4.07 & 2.45 & 0.57 & -0.52 & 0.58 & -0.92 & 0.39 & -1.82 & 0.06 & 0.05 & 0.54 & 0.52 \\
\hline $\mathrm{C}-11 \times \mathrm{G}-60$ & 2.13 & 1.82 & 1.39 & -2.99 & 0.17 & -0.59 & 6.14 & 4.61 & -0.02 & -0.04 & 1.40 & -1.54 \\
\hline C-11 x B-4 & -0.183 & -0.88 & 1.99 & -1.86 & -0.25 & -3.23 & 0.79 & -0.35 & -0.04 & -0.05 & 0.19 & -0.52 \\
\hline C-11 $\times$ B-3 & 1.50 & -7.78 & 1.90 & -0.15 & 0.12 & -2.51 & 0.50 & -0.45 & 0.07 & -0.02 & 0.99 & -1.54 \\
\hline B1.10 x A-35 & 5.20 & 7.85 & 2.29 & 1.72 & 0.96 & -0.27 & 0.59 & -3.12 & 0.04 & -0.01 & 1.24 & 0.53 \\
\hline B1.10 x C-10 & -1.35 & $\begin{array}{l}-6.41 \\
\end{array}$ & 0.29 & 0.08 & $\begin{array}{l}-0.03 \\
\end{array}$ & -2.65 & 4.46 & -5.62 & 0.04 & -0.02 & 0.46 & 0.45 \\
\hline B1.10 x G-60 & -1.25 & 0.95 & 1.07 & 0.87 & 1.41 & -0.31 & 4.07 & -1.52 & 0.05 & 0.11 & 0.59 & -1.74 \\
\hline B1.10 x B-4 & 7.93 & 4.58 & 1.14 & 0.51 & -0.13 & -2.48 & -0.47 & -3.84 & 0.06 & -0.05 & -0.47 & -0.88 \\
\hline B1.10 x B-3 & -10.54 & -6.98 & -0.37 & -3.18 & 2.53 & 0.43 & -6.32 & -6.41 & 0.31 & 0.12 & 0.66 & -1.61 \\
\hline B-2.8 $\times$ A-35 & -9.12 & -4.94 & 2.02 & 1.02 & 3.36 & 2.66 & -0.64 & $\begin{array}{l}-0.69 \\
\end{array}$ & 0.13 & 0.05 & -1.09 & -2.78 \\
\hline B- $2.8 \times$ C- -10 & 0.32 & 9.12 & 1.64 & -0.28 & 0.18 & -2.17 & 0.86 & 0.78 & 0.23 & 0.03 & -0.20 & -1.45 \\
\hline B-2.8 x G-60 & -2.86 & -7.51 & 1.99 & -0.05 & 2.98 & 1.35 & 1.00 & 0.54 & 0.07 & -0.18 & 1.40 & 1.05 \\
\hline B- $2.8 \times$ B-4 & -4.82 & -7.88 & 0.57 & -0.52 & 1.16 & -0.71 & 2.46 & -0.42 & 0.04 & 0.02 & -1.19 & -1.58 \\
\hline B-2.8 $\times$ B-3 & 16.49 & 11.22 & -0.30 & -1.21 & -1.21 & -1.12 & -1.27 & -1.52 & 0.05 & 0.03 & 1.67 & 0.85 \\
\hline S.E. & 7.09 & 9.88 & 2.33 & 1.92 & 1.88 & 1.98 & 1.68 & 1.89 & 0.08 & 0.05 & 1.78 & 1.87 \\
\hline
\end{tabular}

$\mathrm{PH}=$ plant height, $\mathrm{HD}=$ head diameter, $\mathrm{AYP}=$ achene yield per plant, $\mathrm{RWC}=$ relative water content, ELWL $=$ excised leaf water loss, MSI $=$ membrane stability index.

Genetics and Molecular Research 15 (4): gmr15048670 
To conclude, two parents (A-10.8 and G-60) showed maximum (46.7\%) genetic dissimilarity using SSR markers. The line A-10.8 and tester G-60 could be used for further hybrid breeding program because these lines were more divergent parents and have the potential for further development of a local high-yielding hybrid of sunflower. A-10.8 was consistent as a good general combiner for achene yield per plant. Hybrid A-10.8 x G-60 can be used as potential parent for short stature and high-yielding hybrid because of the highest negative SCA of the line A-10.8 for plant height. Therefore, divergent material/parental lines need to be exploited for hybrid seed production. The results in non-stressed and stressed regimes were not consistent for most of the traits, which showed that breeding for drought is more reliable in the target environment. Moreover, the results of this study are preliminary and more research is needed for conformity of the results with different replications and at different locations. At the molecular level, specific primers could also be used for more specific results. Lines screened in this study can be used in further breeding programs. Lines with high achene yield could be combined for better yield.

\section{Conflicts of interest}

The authors declare no conflict of interest.

\section{ACKNOWLEDGMENTS}

Higher Education Commission (HEC) of Pakistan funded this research for PhD studies.

\section{REFERENCES}

Ahmad MW, Ahmed MS and Tahir HN (2012). Combining ability analysis for achene yield and related traits in sunflower (Helianthus annuus L.). Chil. J. Agric. Res. 72: 21-26. http://dx.doi.org/10.4067/S0718-58392012000100004

Darvishzadeh R, Azizi M, Hatami-Maleki H, Bernousi I, et al. (2010). Molecular characterization and similarity relationships among sunflower (Helianthus annuиs L.) inbred lines using some mapped simple sequence repeats. Afri. J. Biotechnol. 43: 7280-7288.

Dehmer KJ and Friedt W (1998). Development of molecular markers for high oleic acid content in sunflower (Helianthus annuus L.). Ind. Crops Prod. 7: 311-315. http://dx.doi.org/10.1016/S0926-6690(97)00063-0

Dhanda SS and Sethi GS (1998). Inheritance of excised-leaf water loss and relative water content in bread wheat (Triticum aestivum). Euphytica 104: 39-47. http://dx.doi.org/10.1023/A:1018644113378

Doyle JJ and Doyle JL (1990). Isolation of plant DNA from fresh tissue. Focus 12: 13-15.

Duca M, Port A, Şestacova T, Siniauskaya M, et al. (2013). Microsatellite marker application in sunflower (Helianthus annuus L.) fingerprinting. Biotechnol. Biotechnol. Equip. 27: 3772-3775. http://dx.doi.org/10.5504/BBEQ.2013.0021

Farshadfar E, Rafiee F and Yghotipoor A (2012). Comparison of the efficiency among half diallel methods in the genetic analysis of bread wheat (Triticum aestivum L.) under drought stress condition. Ann. Biol. Res. 3: 1607-1622.

Hladni N, Miklič V, Jocić CS, Kraljević-Balalić M, et al. (2014). Mode of inheritance and combining ability for plant height and head diameter in sunflower (Helianthus annuus L.). Genetika 46: 159-168. http://dx.doi.org/10.2298/ GENSR1401159H

Human JJ, Toit DD, Bezuidenhout HD and Bruyn LPD (1990). The influence of plant water stress on net photosynthesis and yield of sunflower (Helianthus annuus L.). J. Agron. Crop Sci. 164: 231-241. http://dx.doi.org/10.1111/j.1439$\underline{037 X .1990 . t b 00812 . \mathrm{X}}$

Iqbal A, Sadaqat HA, Khan AS and Amjad M (2011). Identification of sunflower (Helianthus annuus, Asteraceae) hybrids using simple-sequence repeat markers. Genet. Mol. Res. 10: 102-106.http://dx.doi.org/10.4238/vol10-1gmr918

Kempthorne O (1957). An Introduction to Genetics Statistics. John Willey and Sons, Inc., New York.

Khan H, Rahman H, Ahmad H, Ali H, et al. (2008). Magnitude of combining ability of sunflower genotypes in different environments. Pak. J. Bot. 40: 151-160.

Genetics and Molecular Research 15 (4): gmr15048670 
Khan MS, Swati MS, Khalil IH and Iqbal A (2003). Heterosis studies for various characters in sunflower (Helianthus annuus L.). Asian J. Plant Sci. 2: 1010-1014. http://dx.doi.org/10.3923/ajps.2003.1010.1014

Kumar AA, Ganesh M and Jnila P (1998). Combining ability analysis for yield and yield contributing characters in sunflower (Helianthus annuus L.). Ann. Agric. Res. 19: 437-440.

Malik TA (1995). Genetics and breeding for drought resistance in wheat: physio-molecular approaches. PhD thesis, University of Wales.

Mba REC, Stephenson P, Edwards K, Melzer S, et al. (2001). Simple sequence repeat (SSR) markers survey of the cassava (Manihot esculenta Crantz) genome: towards an SSR-based molecular genetic map of cassava. Theor. Appl. Genet. 102: 21-31. http://dx.doi.org/10.1007/s001220051614

Miller JF and Fick GN 1997. Sunflower Genetics. In: Sunflower Technology and Production (Schneiter AA, ed.). Agron. Monogr. 35. ASA. CSSA and SSSA, Madison, 441-495.

Mohyaji M, Moghaddam M, Toorchi M and Valizadeh M (2014). Combining ability analysis in sunflower hybrids under water stress conditions. Int. J. Biosci. 5: 364-373. http://dx.doi.org/10.12692/ijb/5.12.364-373

Mullis KB, Ferré F and Gibbs RA (1994). The polymerase chain reaction. Birkhauser Boston Inc., Cambridge.

Nei M and Li WH (1979). Mathematical model for studying genetic variation in terms of restriction endonucleases. Proc. Natl. Acad. Sci. USA 76: 5269-5273. http://dx.doi.org/10.1073/pnas.76.10.5269

Premchandra GS, Saneoka H and Ogata S (1990). Cell membrane stability, an indicator of drought tolerance, as affected by applied nitrogen in soybean. J. Agric. Sci. 115: 63-66. http://dx.doi.org/10.1017/S0021859600073925

Rauf S (2008). Breeding sunflower (Helianthus annuus L.) for drought tolerance. Commun. Biom. Crop Sci. 3: 29-44.

Razi H and Assad MT (1998). Evaluating variability of important agronomic traits and drought tolerant criteria in sunflower cultivars. J. Water Soil Sci. 2: 31-43.

Singh BD (2000). Plant Breeding: Principles and Methods. Kalyani Publishers, New Delhi.

Sneath PHA and Sokal RR (1973). Numerical taxonomy. W.H. Freeman and Co., San Francisco.

Steel RG, Torrie JH and Dickey DA (1997). Principles and Procedures of Statistics: A biometrical approach. 3rd edn. McGraw-Hill, New York.

Sujatha M, Prabakaran AJ, Dwivedi SL and Chandra S (2008). Cytomorphological and molecular diversity in backcrossderived inbred lines of sunflower (Helianthus annuus L.). Genome 51:282-293.http://dx.doi.org/10.1139/G08-008

Zhang LS, Clerc VL, Li S and Zhang D (2005). Establishment of an effective set of simple sequence repeat markers for sunflower variety identification and diversity assessment. Can. J. Bot. 83: 66-72. http://dx.doi.org/10.1139/b04-155

Zia ZU, Sadaqat HA, Tahir MHN, Sadia B, et al. (2014). Estimation of genetic diversity using SSR markers in sunflower. Genetika 50: 570-580.http://dx.doi.org/10.7868/S0016675814050142

Genetics and Molecular Research 15 (4): gmr15048670 